\title{
Fast Violence, Revolutionary Violence: Black Lives Matter and the 2020 Pandemic
}

\author{
Claire Colebrook
}

Received: 25 June 2020 / Accepted: 5 August 2020

(C) Journal of Bioethical Inquiry Pty Ltd. 2020

\begin{abstract}
The 2020 pandemic cannot be divorced from the problem, pace, and spectacle of race, both because of the racial rhetoric regarding the origins of the virus and because of the subsequent racial injustice in the distribution of healthcare. This paper adds the concept of fast violence to Rob Nixon's "slow violence" to look at the intersection between the climate of the planet and the climate of racial injustice.
\end{abstract}

Keywords Pandemic · Anthropocene · Violence

The Anthropocene is an intensively temporal concept, not because it marks out a span of geological time (which would simply be extensive) but because it marks a time within human history and a certain discipline (geology) where one way of marking time (stratigraphy or the temporality drawn from the earth's layers) intersects with a shift in the understanding of human time. At a certain point in geological history, a species can have geological impact, and at a certain point in human history, the earth's geological time enters the political imaginary. The layers of the earth start to speak to how we might imagine our future; the contraction of our future speeds up. Taking account of the once slow time of geology shows just how narrow our window is for any action that might save the world as we know it. What 2020 has brought to the fore is

C. Colebrook $(\bowtie)$

Pennsylvania State University, University Park, Penn State, State College, PA, USA

e-mail: Cmc30@psu.edu the extent to which the "anthropos" of the Anthropocene and the "we" whose future is imperilled has always been racial (Karera 2019). The speeds and intersections of human and geological time need to be rendered distinct by noting that the "we" of the Anthropocene and the future that is both promised and threatened by humanism were made possible by a history of slavery, in which the private spaces and personal timelines of modern urban existence depended upon a massive interruption and destruction of African time. As Frank Wilderson has argued, so encompassing and universal is the trajectory of "the human," so definitive was the social death demanded of slaves, that anti-blackness becomes definitive of a human time that knows no outside. In the United States especially, the state is premised upon anti-blackness:

Without the sexualized violence against and mass incarceration of hundreds of thousands of Black captives, Americans would not be able to elect a U.S. president. Thomas Jefferson would never have become president. In the late eighteenth and early nineteenth centuries, ... 389,000 [that's less than a half million] ... African slaves, bred like horses or sheep, became four-million enslaved African-Americans ... [T] he forced mating of slaves ... gave slave states more voting power based on the number of slaves they held captive.Virginia was the largest slave-breeding state. As a result, it gained twenty-five percent of the forty-six Electoral College votes, more than enough to send Jefferson to the White House (Wilderson 2020). 
The "anthropos" of the Anthropocene and the "we" of the future can appear as unified only by way of racialized time; "we" can declare ourselves to be participants in a single history and to be suffering from the same tragedy of the commons only after centuries of slavery and colonization. Race appears to be erased in the figure of "the human," even if the geopolitics that produces global interconnectedness relies heavily on outsourcing risk, toxicity, and exposure to those deemed to be less than human. The same racializing universality applies to the global tallies and graphs of the pandemic's curves and statistics. The globalism that tracks, monitors, and distributes life - today as in 1918-depicts humans as a species, but does so while erasing the violence that brought the very experience of "the human" into being. In the United States, deaths were higher among ethnic minorities precisely because the entire economy was structured around distributing risk and vulnerability to those who were essential to an economy that would do very little to protect them. The pandemic, in this respect, made manifest and accelerated the slow violence of the Anthropocene. The intersection of speeds that characterized the 2020 pandemicwhere long-running inequalities resulted in surging death rates in certain parts of the United Statesmirrors centuries of global violence where the steady growth of the world required the sudden destruction of so many worlds.

The Anthropocene as the intrusion of geological forces into the experience of being human was only possible because some humans-slaves-were regarded as energy to be extracted, torn from the ground of existence, and rendered into nothing more than matter for the sake of human progress. Only with that sudden and disruptive violence was anthropos possible. It was in response to the Anthropocene's speeding up of geological time and its impact on human existence that Rob Nixon formed one of the most fruitful concepts to emerge from the environmental humanities: slow violence. For Nixon this concept was tied to "the poor," a concept that from the outset is tied yet once more to Africa. Nixon's first example of slow violence is the transportation of toxic waste to Africa.

In this essay I want to think about slow violence in relation to fast violence. Nixon ties slow violence to time, space, and visibility:

By slow violence I mean a violence that occurs gradually and out of sight, a violence of delayed destruction that is dispersed across time and space, an attritional violence that is typically not viewed as violence at all. Violence is customarily conceived as an event or action that is immediate in time, explosive and spectacular in space, and as erupting into instant sensational visibility. We need, I believe, to engage a different kind of violence, a violence that is neither spectacular nor instantaneous, but rather incremental and accretive, its calamitous repercussions playing out across a range of temporal scales (Nixon 2011,2).

The year 2020 brought to the fore the extent to which slow violence is intertwined with fast violence, the extent to which invisibility is tied to spectacle, and the extent to which outsourcing violence to reduce its visibility and the immediacy of impact could also generate sudden disruptions.

To say that the 2020 pandemic coincided with the spectacle of racial violence is accurate only if one thinks about coincidence less as a chance event and more as the way in which the speeds of violence are always racialized and always fast and slow at the same time. The pandemic was sudden, experienced as a shock to the economy and daily rhythms; the entire purpose of lockdown was to slow down the rate of infection, with the graph of "flattening the curve" becoming a daily obsessive checkpoint in the media. The disease was sudden, its onset sudden, and its spread sudden. More importantly - even though one of the common antilockdown reactions to the disease compared its mortality rate to other accepted forms of mass death such as road vehicle accidents-what made COVID-19 so alarming was the intolerable spectacle of its impact. It is here that Nixon's claims about slow violence allow us to think through the biopolitics of the pandemic, and its specific speed. There is some degree of truth to the claim that "we" accept all sorts of deaths without going into lockdown, but perhaps rather than this being a case for not acting it should prompt us to think about the toll of the everyday life that was ground to a halt. The slow violence of everyday hidden deaths (obesity, hypertension, heart disease, diabetes - all tied to the hyperconsumption of the American way of life) intersected with the fast and intolerable violence of mounting COVID-19 deaths, morgue trucks parked in Manhattan's Park Avenue, surging unemployment, plummeting stock market figures, and sudden ecological changes in urban centres (including the sudden visibility of diminished pollution over densely populated cities and images 
of deserted streets in London and New York that echoed post-apocalyptic cinema). These speeds were made possible by centuries of slow violence: like the 1918 pandemic to which it is so often compared, the spread of COVID-19 was highly racialized (McDonald 2020). The death rates of non-white Americans far exceeded those who had a long history of greater access to healthcare, insurance, decent working conditions, clean water, exercise, and healthy diets. With the president of the United States referring to the "China virus," and "Kung flu," the virus's origins were demonized, even if the global transmission of the virus was made possible by centuries of global trade and tourism that made the West both affluent and vulnerable. The fast racial violence of the virus - its capacity to kill non-white Americans at a faster rate, while providing an opportunity for the United States to intensify racist immigration and border control policies - was preceded and enabled by centuries of slow violence. This slow violence would include the transformation of the earth as a living system but also the ongoing exclusion of poor and minority Americans from healthcare, clean water, and decent living conditions. That slow violence, in turn, was the outcome of sudden and catastrophic events that destroyed worlds overnight, including the four hundred years of slavery that for each enslaved body was both a slow violence of an entire life of unfreedom, accompanied by visible, sudden, and singular events of violence.

The 2020 pandemic in the United States cannot be uncoupled from the speed of violence that became visible in the death of one man, George Floyd, on May 25, 2020. Just as the 1918 flu formed the already racialized backdrop of the lynching of Mary Turner, so the 2020 pandemic brought to the fore the intense affective speeds of violence and vulnerability. As Saidiya Hartman noted with regard to the 1918 pandemic, "for every year between 1906 and 1920, black folks in cities experienced a rate of death that equaled the white rate of death at the peak of the pandemic" (Hartman 2020). Hartman then notes, drawing on the work of Du Bois and Walter White's "The Work of a Mob" from 1918, that the spectacle of lynching would be enough to generate a form of pessimism in which only the end of the world might generate a space for hope. Time is everything: the rate of Black death had been at peak pandemic levels for years, prior to 1918. The sudden and unbearable violence of the death of Mary Turner was, Hartman notes, "so revolting and the details so horrible that as editor Du Bois was reluctant to share them." Slavery had already been an intersection of slow and fast violence, the slow violence of four hundred years of building a racial empire, coupled with the sudden spectacle of lynching. By the time of the 1918 pandemic, those speeds intersected with uneven healthcare and substandard housing for African Americans and then the holocaust of lynchings of 1918.

Violence, speed, and spectacle are always connected, with distance also playing its part. Peter Singer frequently defends utilitarianism by way of an anecdote: you see a child drowning in an amount of water that poses no threat to you, but you will get your clothes muddy and be late for your next appointment. Without question you would save the life of the child, regardless of your attachment to the shine of your Prada loafers. Singer then suggests that we use this anecdote to think about how little we would notice charitable actions that would save lives, but lives that are not-like the child in the anecdote - directly before us:

Once we are all clear about our obligations to rescue the drowning child in front of us, I ask: would it make any difference if the child were far away, in another country perhaps, but similarly in danger of death, and equally within your means to save, at no great cost-and absolutely no danger - to yourself? Virtually all agree that distance and nationality make no moral difference to the situation. I then point out that we are all in that situation of the person passing the shallow pond: we can all save lives of people, both children and adults, who would otherwise die, and we can do so at a very small cost to us: the cost of a new $\mathrm{CD}$, a shirt or a night out at a restaurant or concert, can mean the difference between life and death to more than one person somewhere in the world - and overseas aid agencies like Oxfam overcome the problem of acting at a distance (Singer 1977).

For Singer the point of the exercise is utilitarian: at little cost to us we could do a great deal of good. But the thought experiment also says a great deal about immediacy and the imagination and how we accept at a daily level a very high global death toll for the sake of pleasures and conveniences that, upon reflection, we might forgo. Singer's thought experiment is similar to Nixon's concept of slow violence in this one respect: both assume that re-narration and re-conceptualization would alter the attitudes and actions we adopt towards forms of 
violence that have been insufficiently visible. But perhaps what is at stake is something that exceeds narration and absent mindedness; perhaps the very temporality of "the human" is bound up with a metaphysical or libidinal investment in certain forms of racist destruction? Does the spectacle of morgue trucks in Manhattan and the suddenly apparent inequity of healthcare resources draw attention to the ways in which non-white Americans have borne the brunt of suffering for centuries? Does that attention then lead to a change in action? The preliminary answer to this question has to be "no." The pandemic did make the long slow systemic violence of racism more apparent, with public health officials admitting that the comorbidities that placed individuals at higher risk were going to affect minorities and the poor. Such resignations were background noise; the general focus was primarily on overall counts and trends.

It required another spectacle and temporality to shift this acquiescence of violence in a different direction, and that was the visible and unbearably drawn-out eightminute-and-forty-six-second murder of George Floyd on May 25, 2020. It was this event that took the slow violence of the pandemic - already an effect of climate change, global capitalism, empire, and inequity - and generated the fast revolutionary violence of the Black Lives Matter protests. In his "Critique of Violence," Walter Benjamin marked a critical distinction between violence that maintains the state (law-preserving) and the violence that founds the state (law-making); in both cases violence appears as a means to a seemingly "natural" end (in the violence that founds the state) or as a means to an already-given end (in the legally sanctioned violence that preserves the state). Where this seeming distinction and justification breaks down is in police violence, for it is here that what appears as simply preserving the law often appears as a violent production of legality without ground:

Therefore the police intervene "for security reasons" in countless cases where no clear legal situation exists, when they are not merely, without the slightest relation to legal ends, accompanying the citizen as a brutal encumbrance through a life regulated by ordinances, or simply supervising him. Unlike law, which acknowledges in the "decision" determined by place and time a metaphysical category that gives it a claim to critical evaluation, a consideration of the police institution encounters nothing essential at all. Its power is formless, like its nowhere tangible, all-pervasive, ghostly presence in the life of civilized states (Benjamin 1995, 243).

It follows that opposition to police violence is opposition to the very notion of violence as a means to a natural end. It is this oppositional violence that allowed the protests against police brutality to coincide with the ecological crisis of the pandemic. The death of George Floyd gave immediate and spectacular visibility to the foundational violence that is bound up with global capitalism, climate change, and the volatile conditions of zoonotic viruses (Van Dooren 2020). State-founding violence is at once, as Benjamin has argued, mythically outside all narration and temporality — appearing as if by fate; but it is also, as Anthropocene studies and Black studies have made clear, discernible in all the monuments that mark moments of conquest. The revolutionary violence that demanded the removal of confederate and settler statues was a violence directed against the colonization that destroyed Black lives and the conditions for life in general. Here I would add to the slow violence noted by Nixon and the unbearably slow and therefore visible death of George Floyd, an intensive violence that seeks to undo the world. At a quite practical level it made sense for Black Lives Matter protesters to gather in large protests, not simply in spite of the pandemic - although it could be argued that the risk of contracting COVID-19 at a rally was lower for some non-White Americans than being killed if you answered your own door with a steak knife (Osaze Osagie), or slept in your own bed (Breanna Taylor), or went for a neighbourhood jog (Ahmaud Arbery).

Because of the pandemic, because the world had been interrupted and was poised at a moment of high risk, 2020 might well be the time to engage in a form of civil disobedience that would challenge the structural state violence that coincided in the death of George Floyd. Floyd's death cannot be explained without making some reference to the libidinal investment in the spectacle of Black death. While the nine-minute video of his death was too brutal to watch for some, it provided the occasion for white supremacists to post staged videos of their knee on a friend's neck (Kesslen 2020). Just as the visibility of lynching in 1918 reasserted the power of white "policing" amidst a pandemic that was already taking its toll on black lives, so the 8' 46 " video of Floyd's murder was yet one more occasion in which visible and arbitrary murder of Black men maintained a 
police state (Martinot and Sexton 2003). The protests that responded to this murder retroactively brought attention to recent murders of other Black men and women, and in so doing drew upon the slowing down of time in a pandemic, the general sense of unrest and frustration of lockdown, and a loss of faith in the world. In my own quiet college town of State College, Pennsylvania, large protests recalled the previous year's killing of Osaze Osagie, who was shot by police after his father had called 911 because he was concerned about his son's mental health. In March of 2020 the memorial march for Osagie's death was postponed because of the pandemic. However, following the death of George Floyd and national protests, State College took part in a series of significantly larger gatherings than it had seen or expected prior to the global response to Floyd's murder. If the memorial in March was closed because of the pandemic, by June 2020 the virus that seemed to threaten the world became the occasion to demand the end of the police state. This, I would argue, has been the overall effect of the Trumpocene: there are events that trump the end of the world. In 2016 it might have seemed that the slow violence of climate change and ecological catastrophe would be the global justice issues of our time. But that slow violence then led to a series of catastrophes, including the spectacle of the 2020 pandemic, the racial injustice intensified by that pandemic, and then a sense that this unravelling world might be the occasion for a destruction of a system of policing inextricably intertwined with centuries of Black death. The 2020 pandemic brought risk calculus to popular attention; debates whether saving lives from lockdown would cause greater harms from job loss and depression were accompanied by ghoulish claims that only the weak and elderly would be sacrificed. But these numerical risks and calculations, with their different speeds and distributions, were then overtaken by an event that questioned the very value of the world that lockdowns were seeking to save. From a global response of lockdowns and government rescue bills focused on the economy versus human life, a single visible event showed nine minutes to be a very long time and shifted the calculus of the multitude away from how much time in lockdown would be required to save the world to protests that sought to destroy the world for the sake of life.

\section{References}

Benjamin, W. 1995. Critique of violence. In Selected writings: Volume 1, 1913-1926, edited by M. Bullock and M.W. Jennings, 236-252. Cambridge: Harvard University Press.

Hartman, S. 2020. The end of white supremacy, an American romance. Bomb, June 5. https://bombmagazine. org/articles/the-end-of-white-supremacy-an-americanromance/. Accessed August 3, 2020.

Karera, A. 2019. Blackness and the pitfalls of Anthropocene ethics. Critical Philosophy of Race 7(1): 32-56.

Kesslen, B. 2020. Video shows white men in N.J. mocking George Floyd's death at protest. NBS News, June 10. https://www.nbcnews.com/news/us-news/video-showswhite-men-n-j-mocking-george-floyd-s-n1229051. .

Martinot, S., and J. Sexton. 2003. The avant-garde of white supremacy. Social Identities 9(2): 169-181.

McDonald, S. 2020. In 1918 and 2020, race colors America's response to epidemics: A look at how Jim Crow affected the treatment of African Americans fighting the Spanish flu. The Undefeated, April 1. https://theundefeated. com/features/in-1918-and-2020-race-colors-americasresponse-to-epidemics/. Accessed August 3, 2020.

Nixon, R. 2011. Slow violence and the environmentalism of the poor. Cambridge: Harvard.

Singer, P. 1977. The drowning child and the expanding circle. New Internationalist, April 1977. https://www.utilitarian. net/singer/by/199704\%2D\%2D.htm. Accessed August 3, 2020.

Van Dooren, T. 2020. Pangolins and pandemics: The real source of this crisis is human, not animal. New Matilda, March 2020. https://newmatilda.com/2020/03/22/pangolinsand-pandemics-the-real-source-of-this-crisis-is-human-notanimal/. Accessed August 3, 2020.

Publisher's note Springer Nature remains neutral with regard to jurisdictional claims in published maps and institutional affiliations. 